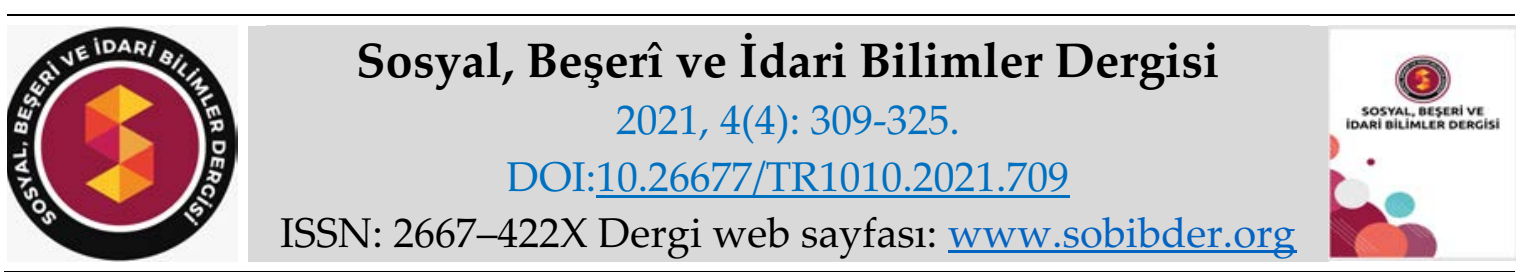

ARAȘTIRMA MAKALESI

\title{
İş Yaşam Dengesi ve İş Doyumu Hastane Çalışanları Örneği
}

Nefise PALABIYIK, Yüksek Lisans Öğrencisi, İstanbul Aydın Üniversitesi, Sosyal Bilimler Enstitüsü, İstanbul, e-posta: nefisepalabiyik@stu.aydin.edu.tr ORCID: https://orcid.org/0000-0001-6479-9905

Dr. Öğr. Üyesi Hakan İşÖZEN, İstanbul Aydın Üniversitesi, Fen-Edebiyat Fakültesi, İstanbul, eposta: hakanisozen@aydin.edu.tr ORCID: https://orcid.org/0000-0001-5784-419X

\section{Öz}

$\mathrm{Bu}$ çalışma ile salgın döneminde, vardiyalı ve uzun çalışma saatlerinin hastane çalışanları üzerindeki iş yaşam ve iş doyumu üzerindeki etkisini ölçmek amaçlanmıştır. Özellikle salgın döneminde uzun saatler çalışan sağlık çalışanlarının yaşadıkları iş doyumu ve iş yaşam dengesine vurgu yapılması bu çalışma ile planlamaktadır. Bu probleme bağlı bu araştırmanın amacı uzun saatler ve vardiyalı çalışmanın yarattığı etkileri iş doyumu ve iş yaşam dengesi üzerinden incelemektir. Çalışmaya 2020 yılının ikinci yarısında İstanbul'da devlet ve özel hastane çalışanlarından toplam 256 kişi dahil edilmiştir. Minnesota iş doyumu ölçeği ve iş yaşam dengesi ölçekleri çalışmada kullanılmıştır. Araştırma sonucuna göre, mesai süresi arttıkça iş yaşam dengesinin bozulduğu, cinsiyetler arasında iş doyum ve iş yaşam dengelerinin farklı olduğu bulunmuştur. Çalışma yılının artışıyla beraber iş yaşam denge puanlarının arttığı ve iş yaşam dengesi ile iş doyumu arasında pozitif yönde anlamlı ilişki bulunmuştur. Diğer bir sonuca göre sürekli gündüz çalışanların iş yaşam denge puanları diğer katılımcılardan yüksek çıkmıştır. Araştırma sonucuna göre iş yaşam dengesi ve iş doyumunun mesai süresi ve vardiyalı çalışma ile etkilenebildiği sonucuna varılmıştır. İş doyumu ile iş-yaşam dengesi arasında pozitif ilişki olduğun bu çalışma ile gösterilmiştir. Özellikle 40 saatin altında çalışan kişilerin iş doyumlarının yüksek olduğu bulunmuştur. Bu yüzden örgütlerin çalışma saatlerini düzenlemesi büyük önem taşımaktadır.

Anahtar Kelimeler: İş Doyumu, İş Yaşam Dengesi, Vardiyalı Çalışma, Sağlık Çalışanı, Stres.

Makale Gönderme Tarihi: 02.01.2021

Makale Kabul Tarihi: 03.04.2021

\section{Önerilen Atıf:}

Palabıyık, N. ve İşözen, H. (2021). İş Yaşam Dengesi ve İş Doyumu Hastane Çalışanları Örneği, Sosyal, Beşeri ve İdari Bilimler Dergisi, 4(4): 309-325.

(C) 2021 Sosyal, Beşerî ve İdari Bilimler Dergisi. 


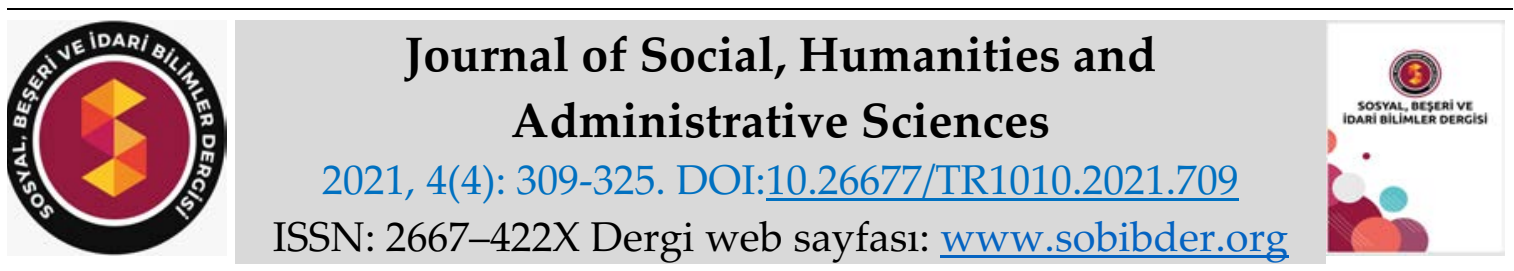

RESEARCH PAPER

\title{
Balance of Business and Personal Life and Job Satisfaction with Healthcare Professionals
}

Nefise PALABIYIK, MSc. Student, İstanbul Aydın University, Social Sciences Institute, İstanbul, e-mail: nefisepalabiyik@stu.aydin.edu.tr ORCID: https://orcid.org/0000-0001-6479-9905

Associate Prof. Dr. Hakan İ̧̧ÖZEN, İstanbul Aydın University, Faculty of Science and Literature, İstanbul, e-mail: hakanisozen@aydin.edu.tr ORCID: https://orcid.org/0000-0001-5784-419X

\begin{abstract}
This study plans to emphasize the job satisfaction and the balance of business and personal life experienced by healthcare professionals who work overtime, especially during the pandemic period. This study plans to emphasize the job satisfaction and work-life balance experienced by healthcare professionals who work long hours, especially during the pandemic period. The purpose of this study is to examine the effects of working long hours and shifts in terms of job satisfaction and work life balance. Research was conducted in Şişli and Zeytinburnu districts of Istanbul. It was conducted in the second half of 2020 on a total of 256 healthcare workers. According to the results of the research, it was found that as the working time increases, the balance of business and personal life deteriorates, and job satisfaction and the balances of business and personal life differ between genders. It was found that the balance of business and personal life scores increased with the rise of time spent in the business life in a lifetime and it was determined a positive significant relationship between the balance of business and personal life and job satisfaction. According to another result, the balance of business and personal life scores of the daytime workers were higher than the other participants (night workers and shift workers). According to the results of the research, it was concluded that the balance of business and personal life and job satisfaction can be affected by working hours and working in shifts. In this study, a positive significant relationship was found between the balance of business and personal life and job satisfaction. Based on the results, if health workers work less than 40 hours per week a positive significant relationship was found with job satisfaction. For this reason, companies should regulate the working hours.
\end{abstract}

Keywords: Job Satisfaction, the Balance of Business and Personal Life, Working in Shifts, Healthcare Professional, Stress

Received: 02.01.2021

Accepted: 03.04.2021

\section{Suggested Citation:}

Palabıyık, N. and İşözen, H. (2021). Balance of Business and Personal Life and Job Satisfaction with Healthcare Professionals, Journal of Social, Humanities and Administrative Sciences, 4(4): 309-325.

(C) 2021 Sosyal, Beşerî ve İdari Bilimler Dergisi. 


\section{Gíriş}

Günümüz iş yaşamında çalışma saatleri sadece gündüz belirli saatler arasında sınırlı kalmayıp, gece ve hafta sonları da devam etmektedir. Özellikle hizmet ve sanayi sektörü gibi alanlarda yirmi dört saat boyunca devam eden vardiya sistemi ile süreçler ilerlemektedir. Sağlık, ulaşım, güvenlik, sanayi gibi sektörlerde çalışan kişiler vardiya esasına dayalı olarak çalışmak durumundadırlar. Türkiye' de çalışan sağlık personeli sayısı T.C. Sağlık Bakanlığı istatistiklerine göre 1 milyon 61 bin 635 kişidir. Doktorların sayısı 165 bin 363 kişi, hemşirelerin sayısı 204 bin 969 kişidir (Türkiye Cumhuriyeti Sağlık Bakanlığı, 2020).

Sağlık sektörü çalışmak için en tehlikeli ortamlardan biridir. Bu sektörde çalışan kişiler çalıştıkları süre boyunca sağlık ve güvenlik tehlikeleri ile karşı karşıya kalmaktadırlar. Tehlikeler hastadan çıkan Hepatit, HIV gibi hastalıklara sebep olan sekresyonlara maruz kalmaktan glutaraldehit ve etilen dioksit gibi kimyasallara maruz kalmaya kadar uzanabilir. Gürültü ve radyasyona maruz kalma gibi fiziksel tehlikelerin yanı sıra ağır kaldırma, uzun süre ayakta kalma gibi ergonomik problemlerde sağlık çalışanlarının karşılaştığı sorunlar arasındadır. Uzun çalışma saatleri ile beraber vardiyalı çalışmakta sağlık sektöründe çalışmanın stresine olumsuz katkıda bulunur (Joseph ve Joseph 2016).

Vardiyalı çalışma sisteminde klasik 8 saat olarak uygulanan çalışmanın günün ikiye ya da üçe bölünmesi ile uygulanmaktadır. Aşırı tüketim taleplerini karşılamak amacıyla vardiyalı çalışma sistemi özellikle 1. Dünya Savaşı ve sonrasında uygulanmaya başlanmıştır. Genellikle sanayi üretiminde uygulanılan vardiyalı çalışma sistemi; güvenlik, sağlık, ulaşım, telekomünikasyon vb. gibi günlük yaşamın vazgeçilmezi durumundaki hizmetlerde de kullanılmaktadır (Yılmaz ve Ekici 2006). Vardiyalı çalışmanın fizyolojik ve psikilojik birçok olumsuz etkisi bulunmaktadır. Uykusuz kalmanın yarattı̆̆ bilişsel fonskiyonlarda bozulma, hem hastanın hem de çalışanın güvenliğini tehlikeye sokmaktadır. Bilişsel fonskyonlardaki bozulma/azalma ile hastanın gereksinimlerine tam olarak dikkat edilememekte, bakım kalitesi düşmekte ve iş kazaları (kendini yaralama ilaç hataları) oluşabilmektedir. Hasta/sağlık çalışanı dengesinin de yeteri kadar ayarlanamaması sonucunda sağlık çalışanı hem fazla iş yükü ile hem de uykusuz kalmanın yarattığ 1 etkiler ile mücadele etmektedir. Fazla iş yükü, biyolojik ritmde bozulma gibi nedenler sonucunda sağlık çalışanının performansı düşer, hata yapma riski artar.

\section{KAVRAMSAL ÇERÇEVE}

\section{İş Stresi}

İş stresi, zarar verici duygusal ve fiziksel tepkiler olarak tanımlanabilir ve işin gereksinimleri işçinin ihtiyaçlarına, yeteneklerine uymadığında ve kaynaklar yetersiz kaldığında ortaya çıkar. İşs stresi sağllğı̆ zayıflamasına hatta yaralanmalara neden olabilir (https://www.cdc.gov/niosh). Birleşmiş Milletler 1992 raporu, iş stresini 20. yüzyılın hastalığı olarak gösterirken, Dünya Sağlık Örgütü, stresin dünya çapında salgın bir hastalık haline geldiğini vurgulamaktadır. Avrupa ülkelerinde iş stresinin maliyetleri her geçen yıl artış göstermektedir, örneğin; Fransa'da 2007 yılı itibari ile iş stresinin ulusal maliyeti 2-3 milyar Euro iken İngiltere'de 2009-2010 yılları arasında 9,8 milyon çalışma gününün stress kaynaklı devamsızlıklar yüzünden kayba uğradığı tespit edilmiştir (European Agency for Safety and Health at Work 2014). Amerika Birleşik Devletleri'nde gerçekleştirilen çalışmaya göre çalışanların yaklaşık yüzde $40^{\prime} ı$ iş stresi ile karşı karşıya kalmaktadır (https://www.cdc.gov/niosh). Özellikle sağlik sektöründe stres kavramı çalışma hayatının parçası durumundadır. Sağlık çalışanları görevleri gereği kaliteli bir hizmet sunmaya odaklanırken maruz kaldıkları bazı örgütsel etmenlerden dolayı zorluk yaşamaktadır. Maruz kalınan etmenler; zaman baskısı, rol belirsizliği, aşırı iş yükü, hizmetlerdeki organizasyon 
ve koordinasyon eksikliği, çalışanlar arasındaki ilişkilerdeki yetersizlik ve personel yetersizliği gibi faktörlerdir (Ebling ve Carlotto 2012).

\section{İş Doyumu}

Bireyin yaptığı işten zevk alması, yaptığı işten sağladığı maddi kazançlar, çalışma sonucunda ortaya çıkan sonuçtan memnuniyet hali hissetmesine iş doyumu denilmektedir (Kaya ve Oğuzöncül, 2016). İş doyumu, organizasyonun verimini ve çalışanların performansını etkileyen temel faktörler arasında sayılmaktadır. Günümüzde organizasyonlar, çalışanların ihtiyaçları ve istekleri doğrultusunda yapılanmanın önemini fark etmeye başlamışlardır. Çalışanların, öncelikle birer birey olduklarına dikkat etmenin organizasyonun verimi için önemli olduğunun farkına varılmaya başlanmıştır. Sonuç olarak işinden doyum alan çalışan mutlu çalışan, mutlu çalışan ise işinden doyum alan çalışandır (Özkul, 2015). Kişi işinden doyum sağlıyorsa, işi ile ilgili olumlu düşünce yapısına sahip olup işinden hoşlanmaktadır. İşinden hoşlanan kişinin verimliliği ile beraber performansıda artacaktır.

\section{İş Yaşam Dengesi}

Toplum sağlı̆̆ için önemli konulardan biri iş yaşam dengesinin kurulmasıdır. İş yaşam dengesinin önemli bir faktörü kişinin işte ne kadar vakit geçirdiğidir İş yaşam dengesi bireylerin rol çatışmasını en aza indirerek, ev ve iş ortamında doyum sağlamasıdır şeklinde tanımlanabilir (Guest, 2002). Çalışlan mesleğe günümüzde çok büyük anlam yüklenmektedir. İnsanlar kendilerini yaptıkları iş ile tanımlamakta, iş dışı zamanlarında da bu kimliklerini kullanmaktadırlar. İş-yaşam dengesizliğinin hem kişi açısından hem de çalışılan kurum açısından çeşitli sonuçları bulunmaktadır. Yapılan çalışmalara göre kadınlar iş-yaşam dengesizliğinden daha çok etkilenmektedir. Oluşan bu dengesizliğin nedeni ise çalışan kadınların birden fazla rol ve aile sorumluluğu üstlenmek durumunda kalmalarıdır (Küçükusta, 2007). Çalışan işinin gerekliliklerini yerine getirirken, aile ve yaşamına ilişkin görevlerini yerine getiremez ya da işinin zorlu çalışma koşulları yaşamını düzenlemesine engel olursa iş yaşam çatışması meydana gelir (Frone ve Mary 1992). İş-yaşam dengesizliği sonucunda oluşan problemlerle baş edebilmek için birey ve kurumların ortak çaba göstermeleri gerekmektedir. Birey bu dengesizlikle etkin olarak mücadele ettiğinde yaşanacak çatışmalar azalacaktır (Rotondo, Carlson ve Kincaid 2003). Aşağıda yer alan tabloda iş yaşam dengesizliğinin örgütsel sonuçları yer almaktadır.

Tablo 1. İş-yaşam Dengesizliğinin Örgütsel Sonuçları

\begin{tabular}{|l|l|}
\hline Doğrudan Maliyetler & Dolaylı Maliyetler \\
\hline Katılım ve aidiyet & Nefret \\
\hline Devamsızlık & Saldırganlık \\
\hline İşgören devri & Güvensizlik \\
\hline Grev-iş yavaşlatma & Düşük bağlılık düzeyi \\
\hline İş başarısı & İnsan ilişkilerinde kalitesizlik \\
\hline Çıktılar & Enerji kaybı \\
\hline İş kazaları & İş tatminsizliği \\
\hline
\end{tabular}

Kaynak: (Quick, Nelson ve Hurrel 1997). 
Birey iş yaşam dengesizliği yaşadığında yukarıda tabloda belirtildiği şekilde örgüte yansıyacak sonuçlar oluşacaktır. Bu sonuçların bazıları direkt maliyet olurken bazıları dolaylı yollarla maliyet oluşumuna sebebiyet verecektir. Bu yüzden kurumların çalışanları için iş yaşam dengelerini ayarlamalarına yardımcı olacak politikalar geliştirmeleri büyük önem taşımaktadır.

\section{YÖNTEM}

$\mathrm{Bu}$ çalışma ile salgın döneminde, vardiyalı ve uzun çalışma saatlerinin hastane çalışanları üzerindeki iş yaşam ve iş doyumu üzerindeki etkisini ölçmek amaçlanmıştır. Özellikle salgın döneminde uzun saatler çalışan sağlık çalışanlarının yaşadıkları iş doyumu ve iş yaşam dengesine vurgu yapılması bu çalışma ile planlamaktadır. Bu probleme bağlı bu araştırmanın amacı uzun saatler ve vardiyalı çalışmanın yarattığı etkileri iş doyumu ve iş yaşam dengesi üzerinden incelemektir.

\section{Alt Problemler}

1. Sağlık sektöründe vardiyalı çalışma, iş doyumu üzerinde çalışanların cinsiyetlerine göre farklıdır.

2. Sağlık sektöründe vardiyalı çalışma, iş-yaşam dengesi üzerinde çalışanların cinsiyetlerine göre farklıdır.

3. Vardiyalı çalışan ve vardiyalı çalışmayan sağlık sektörü çalışanlarının iş yaşam dengeleri farklıdır.

4. Vardiyalı çalışan ve vardiyalı çalışmayan sağlık sektörü çalışanlarının iş doyum düzeyleri farklıdır.

5. Sağlık çalışanlarının iş yaşam dengesi üzerinde iş doyumunun pozitif yönde anlamlı bir etkisi vardır.

6. Çalışma yılının artışıyla iş yaşam dengesi arasında pozitif yönde anlamlı bir ilişki vardır.

7. Mesai süresi arttıkça iş doyum düzeyi azalır.

8. Salgın döneminde fazla mesaiye çağrılmayan sağlık çalışanlarının iş doyumları daha yüksektir.

Çalışma İstanbul'da bulunan özel ve devlet hastanesinde görevli toplam 256 sağlık çalışanı üzerinde 2020 yılının ikinci yarısında yapılmıştır. Katılan gruptan 131 kişi devlet çalışanı olup, 125 kişi özel kurum çalışanıdır. Katılanlardan 152 kişi kadın olup 104 kişi erkektir. Gündüz çalışma grubu; sürekli gündüz çalışan gece çalışmayanı, gece çalışma grubu; sürekli gece çalışanı, vardiyalı çalışma grubu ise 8-12 saatlik döngülerle gece ve gündüz çalışanları tanımlamak için kullanılmıştır. Minnesota iş doyum ölçeği ve iş yaşam dengesi ölçekleri kullanılarak değerlendirmeler yapılmıştır. Çalışma etik kurul tarafından onaylanmış olup anket yolu ile katılımcılara ulaşılmıştır.

\section{Veri Toplama Araçları}

Demografik Bilgi Formu: Bu form araştırmacı tarafından hazırlanmış olup, katılımcların sosyodemografik verilerini ölçmek amacıyla hazırlanmıştır. Araştırmaya gönüllü olarak katılanlara; cinsiyet, yaş, çalı̧̧ma süresi, öğrenim durumu, meslek, haftalık çalışma saati gibi sorular yöneltilmiş olup, toplam 12 sorudan oluşmaktadır. 
Minnessota İş Doyumu Ölçeği: Sağlık sektöründe çalışan kişilerin iş doyumlarını ölçmek amacıyla Minnesota İş Doyumu Ölçeği (Minnessota Job Satisfaction Questionnaire) kullanılmıştır. Dawis ve arkadaşları tarafından 1967 yılında geliştirilen bir ölçek olup, 1985 yılında Türkçe uyarlaması Baycan tarafından yapılmıştır. Ölçeğin uzun formu 100 soruyu içerirken kısa formu 20 soruyu içermektedir. Çalışmada pratik olması açısında 20 sorulu kısa form olan beşli Likert tipi ölçek kullanılmıştır. Ölçekte yer alan her soruda kişinin memnunluk durumunu ifade eden "hiç memnun değilimden çok memnunum" a kadar toplam beş seçenek yer almaktadır. Bu ölçek ile genel doyum, içsel doyum ve dışsal doyum ölçülmektedir. İçsel doyum kategorisindeki maddeler başarı, sorumluluk, işin kendisi, yaratıcılık gibi faktörlerden oluşmaktadır. Dışsal doyum kategorisindeki maddeler, kurum politikası, kişiler arası ilişkiler, yönetici, ücret gibi faktörlerden oluşmaktadır. Genel doyum puanı hesaplanırken, bütün maddelerin puanlarının toplanılıp 20'ye bölünmesiyle oluşturulur. İçsel doyum puanı, içsel doyumu oluşturan maddelerin toplam puanının 12'ye bölünmesiyle oluşturulurken, dışsal doyum puanı, dışsal doyumu oluşturan toplam maddelerin 8'e bölünmesiyle hesaplanır.

İş yaşam dengesi ölçeği: Çiğdem Apaydın (Apaydın 2011) tarafından çalışanların iş ve yaşamları arasındaki dengeyi ölçmek için geliştirilmiştir. 4 boyut ve 20 maddeden oluşan, 5'li Likert tipi bir ölçme aracıdır. Ölçeğin, 'işyaşam uyumu', 'yaşamı ihmal etme', 'kendine zaman ayırma', 'yaşamın işten ibaret olması' başlıklarında alt boyutları bulunmaktadır. Ölçeğin toplamına ilişkin iç tutarlılık katsayısı, 91'dir. Dört alt boyutun güvenirlik katsayıları ise; iş-yaşam uyumu .88, yaşamı ihmal etme .81, kendine zaman ayırma .77, yaşamın işten ibaret olması .79 şeklindedir.

\section{Verilerin Analizi}

Veri toplama ölçekleri aracılığıyla elde edilen veriler bilgisayar ortamına sayısal ifade olarak girilmiştir. Bu veriler için istatistik paket programı IBM SPSS Statistics 25.0 (IBM SPSS Statistics for Windows, Version 25.0. Armonk, NY: IBM Corp.) kullanılmıştır. Tüm analizlerde anlamlılık düzeyi 0,05 olarak belirlenmiştir.

\section{ANALIZ ve BULGULAR}

Toplam katılımcı sayısı 256 olup katılımcıların \% 59.4'ü kadın, \% 40.6'sı erkek olarak dağıldıkları görülmüştür. En çok katılımcı sayısı 85 kişi ile 26-35 yaş arası olup sırasıyla 70 kişi ile 36-45 yaş grubu, 48 kişi ile $46-55$ yaş grubu, 34 kişi ile 25 yaş ve altı grup en az katılımcı ise 19 kişi ile 56 yaş ve üzerinde olan kişilerden oluşmaktadır.

İlköğretim mezunu katılımcıların oranı \% 5.5, sırasıyla Lise mezunu \% 14.8, Ön Lisans mezunu \% 24.6, Lisans mezunu \% 25, Yüksek Lisans/Doktora mezunu \% 30.1'dir. Eğitim bilgilerine göre katılımcları sıraladığımızda ön lisans ve lisans mezunlarının birbirine yakın sayıda "63-64" oldukları gözükürken, 77 kişi yüksek lisans/doktora mezunu olup, en az katılımcı sayısı 14 kişi ile ilköğretim mezunları arasında yer almaktadır.

Katılımcılardan hasta bakıcı/porter olarak çalışan oranı \% 9.4, sırasıyla hemşire \% 36.7, doktor \% 23.8 , sağlık teknisyeni \% 30.1 kişidir. Bekar kişi oranı \% 40.2, evli kişi sayısı \% 59.8'dir. 
Tablo 1. Demografik Özelliklerin Dağılımı

\begin{tabular}{|lllc|}
\hline Değişken & Adı & Frekans & $(\%)$ \\
\hline Cinsiyet & Kadın & 152 & 59.4 \\
& Erkek & 104 & 40.6 \\
Yaş & 25 yaş ve altı & 34 & 13.2 \\
& 26-35 yaş & 85 & 33.2 \\
& $36-45$ yaş & 70 & 27.4 \\
& 46-55 yaş & 48 & 18.8 \\
Eğitim & 56 yaş ve üzeri & 19 & 7.4 \\
& İlköğretim mezunu & 14 & 5.5 \\
& Lise mezunu & 38 & 14.8 \\
& Ön Lisans mezunu & 63 & 24.6 \\
& Lisans mezunu & 64 & 25.0 \\
Meslek & Yüksek Lisans/Doktora & 77 & 30.1 \\
& Hasta bakııı & 24 & 9.4 \\
& Hemşire & 94 & 36.7 \\
& Doktor & 61 & 23.8 \\
Medeni Durum & Sağllk teknisyeni & 77 & 30.1 \\
& Bekar & 103 & 40.2 \\
& Evli & 153 & 59.8 \\
\hline
\end{tabular}

Tablo 2. Demografik Özelliklerin Dağılımı

\begin{tabular}{|llcc|}
\hline Değişken & Adı & Frekans & Yüzde (\%) \\
\hline Çalışma şekli & Sürekli gündüz & 120 & 46.9 \\
& Sürekli gece & 5 & 2 \\
& Vardiya değişimli & 131 & 51.1 \\
Çalışma yılı & & & \\
& 5 yıldan az & 40 & 15.6 \\
& 6-10 yıl & 40 & 15.6 \\
& $11-15$ yıl & 63 & 24.6 \\
& $16-20$ yıl & 54 & 21.1 \\
Çalışma şeklinin etkisi & Olumlu & 59 & 23.1 \\
& Olumsuz & & \\
& Etkilemiyor & 61 & 23.8 \\
Fazla mesai & & 125 & 48.8 \\
& Evet & 70 & 27.4 \\
Vardiya memnuniyet fazla & Evet & 130 & 50.8 \\
& Hayır & 49.2 & 126 \\
& Bilmiyorum & 43 & 20.7 \\
& & 93 & 36.3 \\
Haftalık mesai & 40 saat & 110 & 43 \\
& 60 saat & & \\
& 60 saat üstü & 178 & 25.4 \\
& & 13 & 69.5 \\
& & & 5.1 \\
\hline
\end{tabular}


Çalışma şekli bilgilerine göre katılımcıları sıraladığımızda 131 kişi vardiya dönüşümü şeklinde çalışıyorken, 120 kişi kişi sürekli gündüz vardiyasında çalıştı̆̆ını ifade etmiştir. En az katılımcı 5 kişi ile sürekli gece vardiyasında çalıştı̆̆ını belirtmiştir. Toplam çalışma süresi 5 yıldan az olan kişi sayısı \% 15.6, 6-10 yıl olan kişi sayısı \% 15.6 , 11-15 yıl olan kişi sayısı \% 24.6, 16-20 yıl olan kişi sayısı \% 21,1, 20 yıldan fazla çalışan kişi sayısı \% 23.1 kişidir. Toplam çalışma yılı bilgilerine göre katılımcıları sıraladığımızda katılımcı sayıları birbirine yakın olmakla beraber en yüksek katılımcı 63 kişi ile 11-15 yıl arasındaki katılımcılardan oluşurken, sırasıyla 59 kişi ile 20 yıldan fazla çalışan grubu, 54 kişi ile 16-20 yıl çalışan grubu, 40'ar kişi ile 5 yıldan az ve 6-10 yıl arası çalışan grubu yer almaktadır. Salgın döneminde fazla mesaiye çağrılma durumları hakkında verilen cevaplara bakıldığında cevapların birbirine yakın olduğu görülmektedir. 130 kişi evet şeklinde cevap verirken 126 kişi hayır şeklinde cevap vermiştir. Çalışanların çalışma şekli ve çalışma saatlerinin kişisel yaşamlarına etkisi konusunda olumlu cevap veren kişi sayısı \% 23.8, olumsuz cevap veren kişi sayısı \% 48.8 , etkilemiyor şeklinde cevap veren kişi sayısı $\% 27.4$ kişidir. Çalışma şekli ve çalışma saatlerinin kişisel yaşamlarına etkisi konusunda katılımcıların verdiği cevaplara bakıldığında 125 kişi olumsuz etkilediğini ifade ederken, 70 kişi etkilemediğini, 61 kişi olumlu etkilediğini belirtmiştir. Vardiyalı çalışmaktan memnuniyet durumu sorulduğunda 110 kişi bilmiyorum, sırasıyla 93 kişi hayır ve 43 kişi evet şeklinde cevap vermiştir. Haftalık mesai sürelerine verilen cevaplara bakıldığında en yüksek oranla 60 saate kadar çalıştığını ifade eden kişi sayısı 178 olup, sırasıyla 40 saate kadar 65 kişi ve 60 saatten fazla çalışan kişi sayısı da 13 kişidir. Katılımcıların yaklaşık \% 70'inin 60 saate kadar çalıştığı göze çarpmaktadır. Çalıştıkları kurum hakkında verilen cevaplarda ise yanıtların birbirine yakın olduğu görülmektedir. Devlette çalışan kişi sayısı 131 iken, özel kurumda çalışan kişi sayısı 125 kişidir.

Tablo 3. Ölçme Araçlarına Ait Alfa Katsayıları

\begin{tabular}{|c|c|c|c|c|}
\hline Ölçek & Faktörler & $\begin{array}{c}\text { Cronbach Alfa } \\
\text { Katsayısı }\end{array}$ & $\underset{\text { değeri }}{p}$ & $\begin{array}{c}\text { Ölçeğin Cronbach } \\
\text { Alfa Katsayısı }\end{array}$ \\
\hline \multirow{4}{*}{ İş-Yaşam Dengesi } & $\begin{array}{l}\text { İş-Yaşam } \\
\text { Uyumu }\end{array}$ & 0,900 & $<0,001$ & \multirow[t]{4}{*}{0,908} \\
\hline & $\begin{array}{l}\text { Yaşamı İhmal } \\
\text { Etme }\end{array}$ & 0,645 & $<0,001$ & \\
\hline & $\begin{array}{l}\text { Kendine Zaman } \\
\text { Ayırma }\end{array}$ & 0,687 & $<0,001$ & \\
\hline & $\begin{array}{l}\text { Yaşamın İşten } \\
\text { İbaret Olması }\end{array}$ & 0,774 & $<0,001$ & \\
\hline \multirow{2}{*}{ İş Doyum } & İçsel Doyum & 0,900 & $<0,001$ & \multirow[t]{2}{*}{0,934} \\
\hline & Dişsal Doyum & 0,886 & $<0,001$ & \\
\hline
\end{tabular}

Tablo 3 incelendiğinde İş-Yaşam Dengesi ölçeği 4 alt boyuttan oluşmaktadır. Madde 1, Madde 4, Madde 10, Madde 5, Madde 2, Madde 13, Madde 12, Madde 20, Madde 18, Madde 15, Madde 14, Madde 16 ters maddelerdir. İş-Yaşam Dengesi Ölçeğini oluşturan ifadelere uygulanan güvenirlik analizi sonucunda, Cronbach Alfa katsayısı 0,908 olarak hesaplanmıştır. Alt boyutlarından İşYaşam Uyumu ölçeğini oluşturan ifadelerin Cronbach Alfa katsayısı 0,900, Yaşamı İhmal Etme ölçeğini oluşturan ifadelerin Cronbach Alfa katsayısı 0,645, Kendine Zaman Ayırma ölçeğini oluşturan ifadelerin Cronbach Alfa katsayısı 0,687, Yaşamın İşten İbaret Olması ölçeğini 
oluşturan ifadelerin Cronbach Alfa katsayısı 0,774 olarak hesaplanmıştır. Ölçeğin güvenirliğinin yeterli düzeyde olduğu gözlenmiştir.

İş Doyum ölçeği 2 alt boyuttan oluşmaktadır. İş Doyum Ölçeğini oluşturan ifadelere uygulanan güvenirlik analizi sonucunda, Cronbach Alfa katsayısı 0,934 olarak hesaplanmıştır. Alt boyutlarından İçsel Doyum ölçeğini oluşturan ifadelerin Cronbach Alfa katsayısı 0,900, Dışsal Doyum ölçeğini oluşturan ifadelerin Cronbach Alfa katsayısı 0,886 olarak hesaplanmıştır. Ölçeğin güvenirliğinin yüksek düzeyde olduğu gözlenmiştir.

Tablo 4. Cinsiyet/İ̧̧ Doyumu

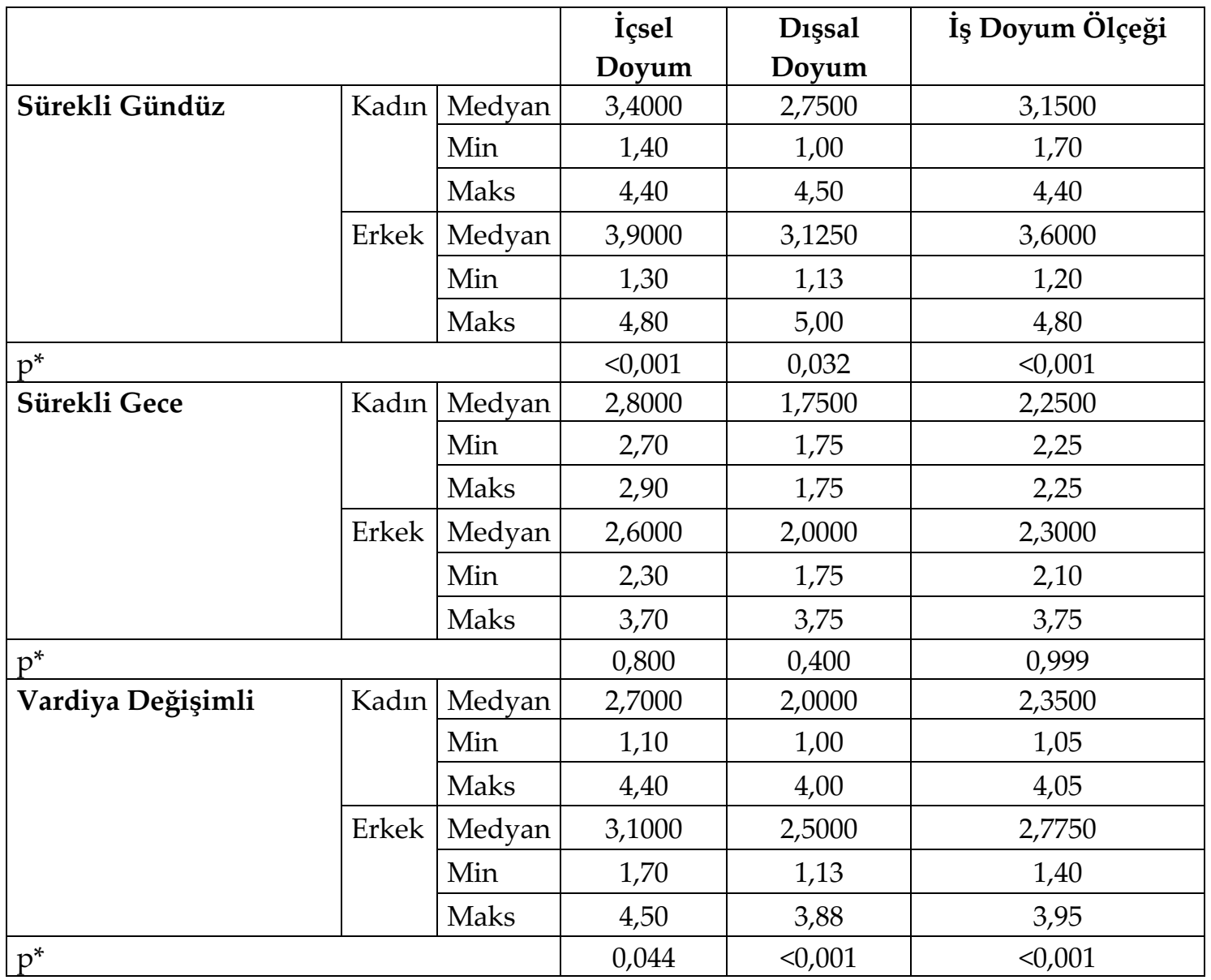

* Mann Whitney U testi

Tablo 4'ye göre sürekli gündüz vardiyasında görev yapan erkek katılımcıların iş doyum puanları daha yüksek çıkmıştır. Vardiya değişimi ile çalışan katılımcılar arasında yine erkek katılımcıların iş doyum puanlarının yüksek çıktığı görülmüştür. Bu tabloya göre erkek ve kadın katılımcılara arasında iş doyumunun farklılık gösterdiğini söyleyebiliriz. 
Tablo 5. Cinsiyet/İş Yaşam Dengesi

\begin{tabular}{|c|c|c|c|c|c|c|c|}
\hline & & & $\begin{array}{c}\text { İş- } \\
\text { Yaşam } \\
\text { Uyumu }\end{array}$ & $\begin{array}{l}\text { Yaşamı } \\
\text { İhmal } \\
\text { Etme }\end{array}$ & $\begin{array}{c}\text { Kendine } \\
\text { Zaman } \\
\text { Ayırma }\end{array}$ & $\begin{array}{l}\text { Yaşamın } \\
\text { İşten } \\
\text { İbaret } \\
\text { Olması }\end{array}$ & $\begin{array}{c}\text { İş Yaşam } \\
\text { Dengesi Ölçeği }\end{array}$ \\
\hline Sürekli Gündüz & Kadın & Medyan & 3,0000 & 3,3333 & 3,5000 & 3,2500 & 3,2500 \\
\hline & & Min & 1,33 & 1,33 & 1,75 & 1,00 & 1,70 \\
\hline & & Maks & 5,00 & 4,00 & 5,00 & 5,00 & 4,65 \\
\hline & Erkek & Medyan & 3,5000 & 3,5000 & 3,7500 & 3,5000 & 3,6000 \\
\hline & & Min & 1,33 & 2,33 & 1,25 & 1,75 & 2,30 \\
\hline & & Maks & 5,00 & 4,83 & 5,00 & 5,00 & 4,85 \\
\hline $\mathrm{p}^{*}$ & & & 0,020 & 0,037 & 0,006 & 0,185 & 0,005 \\
\hline Sürekli Gece & Kadın & Medyan & 2,9167 & 3,3333 & 3,3750 & 4,1250 & 3,3250 \\
\hline & & Min & 2,00 & 3,17 & 2,50 & 4,00 & 3,25 \\
\hline & & Maks & 3,83 & 3,50 & 4,25 & 4,25 & 3,40 \\
\hline & Erkek & Medyan & 3,3333 & 3,1667 & 2,7500 & 3,2500 & 3,3500 \\
\hline & & Min & 2,00 & 2,50 & 2,00 & 1,75 & 1,95 \\
\hline & & Maks & 3,83 & 4,17 & 3,75 & 3,50 & 3,55 \\
\hline $\mathrm{p}^{*}$ & & & 0,999 & 0,800 & 0,800 & 0,200 & 0,999 \\
\hline Vardiya & Kadın & Medyan & 2,1667 & 2,5000 & 2,7500 & 2,5000 & 2,4000 \\
\hline Değişimimli & & Min & 1,00 & 1,00 & 1,50 & 1,00 & 1,30 \\
\hline & & Maks & 4,33 & 4,67 & 4,25 & 4,50 & 4,05 \\
\hline & Erkek & Medyan & 2,8333 & 3,0000 & 3,2500 & 3,0000 & 3,0500 \\
\hline & & Min & 1,33 & 1,50 & 1,50 & 1,25 & 1,95 \\
\hline & & Maks & 4,33 & 4,00 & 4,75 & 4,50 & 3,90 \\
\hline $\mathrm{p}^{*}$ & & & 0,022 & $<0,001$ & 0,001 & 0,062 & 0,005 \\
\hline
\end{tabular}

*:Mann Whitney U testi

Tablo 6. Vardiyalı Çalışan

\begin{tabular}{|l|l|c|c|c|c|c|}
\hline \multicolumn{2}{|c|}{} & $\begin{array}{c}\text { İş- } \\
\text { Yaşam } \\
\text { Uyumu }\end{array}$ & $\begin{array}{c}\text { Yaşamı } \\
\text { İhmal } \\
\text { Etme }\end{array}$ & $\begin{array}{c}\text { Kendine } \\
\text { Zaman } \\
\text { Ayırma }\end{array}$ & $\begin{array}{c}\text { Yaşamın } \\
\text { İşten İbaret } \\
\text { Olması }\end{array}$ & $\begin{array}{c}\text { İş Yaşam } \\
\text { Dengesi } \\
\text { Ölçeği }\end{array}$ \\
\hline \multirow{3}{*}{ Sürekli Gündüz } & Medyan & 3,0000 & 3,3333 & 3,5000 & 3,5000 & 3,3000 \\
\cline { 2 - 7 } & Min & 1,33 & 1,33 & 1,25 & 1,00 & 1,70 \\
\cline { 2 - 7 } & Maks & 5,00 & 4,83 & 5,00 & 5,00 & 4,85 \\
\hline \multirow{4}{*}{ Sürekli Gece } & Medyan & 3,3333 & 3,1667 & 2,7500 & 3,5000 & 3,3500 \\
\cline { 2 - 7 } & Min & 2,00 & 2,50 & 2,00 & 1,75 & 1,95 \\
\cline { 2 - 7 } & Maks & 3,83 & 4,17 & 4,25 & 4,25 & 3,55 \\
\hline \multirow{4}{*}{ Vardiya Değişimli } & Medyan & 2,5000 & 2,6667 & 3,0000 & 2,7500 & 2,7500 \\
\cline { 2 - 7 } & Min & 1,00 & 1,00 & 1,50 & 1,00 & 1,30 \\
\cline { 2 - 7 } & Maks & 4,33 & 4,67 & 4,75 & 4,50 & 4,05 \\
\hline \multirow{2}{*}{$\mathrm{p}^{*}$} & 0,001 & $<0,001$ & $<0,001$ & $<0,001$ & $<0,001$ \\
\hline
\end{tabular}

${ }^{*}$ :Kruscal Wallis testi 
Tablo 5'e göre sürekli gündüz vardiyasında görev yapan katılımcıların İş-Yaşam Uyumu, Yaşamı İhmal Etme, Kendine Zaman Ayırma, Yaşamın İşten İbaret Olması Ölçeği, İş Yaşam Dengesi Ölçeği cinsiyete göre fark yoktur.

Vardiya değişimli çalışanların cinsiyete göre İş-Yaşam Uyumu, Yaşamı İhmal Etme, Kendine Zaman Ayırma, İş Yaşam Dengesi Ölçeği cinsiyete göre fark vardır. Bu sonuca göre iş yaşam dengesi ve cinsiyet değişkeni kısmen kabul edilmiştir.

Tablo 6'e göre iş yaşam dengesi medyan puanları incelediğinde sürekli geceyi çıkardığımızda sürekli gündüz medyan puanı, vardiya değişimliden yüksek çıktığı görülmüştür. Buna göre sürekli gündüz çalışanların iş yaşam denge puanları daha yüksektir.

Tablo 7. İş Doyumu

\begin{tabular}{|l|l|c|c|c|}
\hline \multicolumn{2}{|l|}{} & İçsel Doyum & Dişsal Doyum & İş Doyum Ölçeği \\
\hline \multirow{3}{*}{ Sürekli Gündüz } & Medyan & 3,6000 & 2,8750 & 3,3000 \\
\cline { 2 - 5 } & Min & 1,30 & 1,00 & 1,20 \\
\cline { 2 - 5 } & Maks & 4,80 & 5,00 & 4,80 \\
\hline \multirow{3}{*}{ Sürekli Gece } & Medyan & 2,7000 & 1,7500 & 2,2500 \\
\cline { 2 - 5 } & Min & 2,30 & 1,75 & 2,10 \\
\cline { 2 - 5 } & Maks & 3,70 & 3,75 & 3,75 \\
\hline Vardiya Değişimli & Medyan & 2,8000 & 2,2500 & 2,5500 \\
\cline { 2 - 5 } & Min & 1,10 & 1,00 & 1,05 \\
\cline { 2 - 5 } & Maks & 4,50 & 4,00 & 4,05 \\
\hline $\mathrm{p}^{*}$ & & $<0,001$ & $<0,001$ & $<0,001$ \\
\hline
\end{tabular}

* Kruscal Wallis testi

Tablo 7'e göre sürekli Gündüz, Sürekli Gece ve Vardiya değişimli görev yapan katılımcıların İçsel Doyum, Dışsal Doyum ve İş Doyum Ölçeği ortalama medyan puanları vardiyalı çalışma grupları arasında istatistiksel olarak anlamlı farklılık vardır $(\mathrm{p}<0,001)$. Sürekli Gündüz vardiyasında görev yapan katılımcıların İçsel Doyum, Dışsal Doyum ve İş Doyum Ölçeği ortalama medyan puanları diğer vardiya grubunda yer alan katılımcılardan daha yüksektir.

Tablo 8 İş yaşam ve İş Doyumu

\begin{tabular}{|l|l|c|c|c|c|c|}
\hline \multicolumn{2}{|l|}{} & $\begin{array}{c}\text { İş-Yaşam } \\
\text { Uyumu }\end{array}$ & $\begin{array}{c}\text { Yaşamı } \\
\text { İhmal Etme }\end{array}$ & $\begin{array}{c}\text { Kendine } \\
\text { Zaman } \\
\text { Ayırma }\end{array}$ & $\begin{array}{c}\text { Yaşamın İşten } \\
\text { İbaret Olmasi }\end{array}$ & $\begin{array}{c}\text { İş̧ Yaşam } \\
\text { Dengesi } \\
\text { Ölçeği }\end{array}$ \\
\hline \multirow{2}{*}{ İçsel Doyum } & $\mathrm{r}$ &, $560^{* *}$ &, $475^{* *}$ &, $559^{* *}$ &, $515^{* *}$ &, $663^{* *}$ \\
\cline { 2 - 7 } & $\mathrm{p}^{*}$ & 0,000 & 0,000 & 0,000 & 0,000 & 0,000 \\
\cline { 2 - 7 } & $\mathrm{N}$ & 256 & 256 & 256 & 256 & 256 \\
\hline \multirow{2}{*}{ Dişsal Doyum } & $\mathrm{r}$ &, $533^{* *}$ &, $577^{* *}$ &, $572^{* *}$ &, $522^{* *}$ &, $660^{* *}$ \\
\cline { 2 - 7 } & $\mathrm{p}^{*}$ & 0,000 & 0,000 & 0,000 & 0,000 & 0,000 \\
\cline { 2 - 7 } & $\mathrm{N}$ & 256 & 256 & 256 & 256 & 256 \\
\hline \multirow{2}{*}{ İş Doyum Ölçeği } & $\mathrm{r}$ &, $571^{* *}$ &, $555^{* *}$ &, $606^{* *}$ &, $548^{* *}$ &, $702^{* *}$ \\
\cline { 2 - 7 } & $\mathrm{p}^{*}$ & 0,000 & 0,000 & 0,000 & 0,000 & 0,000 \\
\cline { 2 - 7 } & $\mathrm{N}$ & 256 & 256 & 256 & 256 & 256 \\
\hline
\end{tabular}

* Spearman Korelasyon Analizi 
Tablo 8'ya göre katılımcıların iş doyumu arttıkça iş-yaşam dengelerinin de arttı̆̆ gözlenmektedir. İş doyumu ile iş-yaşam dengesi arasında pozitif yönde yüksek düzeyde ilişki vardır.

Tablo 9'ye göre İçsel Doyum Medyan puanları incelendiğinde 40 saate kadar mesaisi olan katılımcıların İçsel Doyum medyan puanı 60 saate kadar ve 60 saatten fazla olan katılımcıların medyan puanından daha yüksek olduğu söylenebilir $(\mathrm{p}<0,05)$.

Tablo 9. Haftalık Mesai

\begin{tabular}{|l|l|c|c|c|}
\hline \multicolumn{2}{|l|}{} & İçsel Doyum & Dişsal Doyum & İş Doyum Ölçeği \\
\hline \multirow{4}{*}{40 saate kadar } & Medyan & 3,5000 & 2,8750 & 3,2000 \\
\cline { 2 - 5 } & Min & 1,30 & 1,00 & 1,20 \\
\cline { 2 - 5 } & Maks & 4,80 & 5,00 & 4,80 \\
\hline \multirow{4}{*}{60 saate kadar } & Medyan & 3,1500 & 2,3750 & 2,7000 \\
\cline { 2 - 5 } & Min & 1,40 & 1,00 & 1,40 \\
\cline { 2 - 5 } & Maks & 4,50 & 4,50 & 4,40 \\
\hline 60 saatten fazla & Medyan & 2,8000 & 2,2500 & 2,4500 \\
\cline { 2 - 5 } & Min & 1,10 & 1,00 & 1,05 \\
\cline { 2 - 5 } & Maks & 4,80 & 4,75 & 4,80 \\
\hline $\mathrm{p}^{*}$ & & 0,002 & 0,003 & 0,001 \\
\hline
\end{tabular}

${ }^{*}:$ Kruscal Wallis testi

Tablo 10. Salgin Döneminde Fazla Mesai

\begin{tabular}{|l|l|c|c|c|}
\hline \multicolumn{2}{|l|}{} & İçsel Doyum & Dişsal Doyum & İş Doyum Ölçeği \\
\hline \multirow{3}{*}{ Evet } & Medyan & 3,1000 & 2,3750 & 2,7000 \\
\cline { 2 - 5 } & Min & 1,10 & 1,00 & 1,05 \\
\cline { 2 - 5 } & Maks & 4,50 & 4,50 & 4,40 \\
\hline \multirow{3}{*}{ Hayır } & Medyan & 3,3000 & 2,7500 & 3,1250 \\
\cline { 2 - 5 } & Min & 1,40 & 1,00 & 1,70 \\
\cline { 2 - 5 } & Maks & 4,80 & 5,00 & 4,80 \\
\hline $\mathrm{p}^{*}$ & 0,010 & $<0,001$ & 0,002 \\
\hline
\end{tabular}

* Mann Whitney U testi

Tablo 10'e göre salgın döneminde fazla mesaiye çağrılmayan katılımcıların İçsel Doyum, Dışsal Doyum ve İş Doyum Ölçeği ortalama medyan puanları fazla mesaiye çağrılan katılımcılardan daha yüksektir.

Araştırma sonuçlarına göre erkek ve kadın katılımcıların arasında iş doyumunun farklılık gösterdiğini belirtebiliriz. Erkeklerin kadınlardan daha yüksek çıkmıştır. Bunun nedeni olarak kadınların hem iş hem aile hayatındaki iş yüklerinin fazla olması şeklinde yorumlayabiliriz. İş yaşam dengesi konusunda cinsiyete göre kısmen farklılık oluştuğu için hem kadın, hem erkek sağlık çalışanlarının yoğun çalışma tempoları nedeniyle iş yaşam dengesini kurmakta 
zorlandıklarını düşünebiliriz. Vardiya değişimli ve sürekli gündüz çalışanlara baktığımızda iş doyumu arasında farklılık ortaya çıkmaktadır. Sürekli gündüz çalışanların iş doyumları daha yüksektir. Bunun nedeni olarak gece vardiyası sırasında az personel ile çalışma, yoğun hasta grubu ile ilgilenmek durumunda kalma, uykusuzluğun ve yorgunluğun daha fazla hissedilmesi gibi etkenlerin olduğunu varsayabiliriz. İş doyumu ile iş-yaşam dengesi arasında pozitif yönde yüksek düzeyde ilişki olduğu yine bir başka sonuç olarak karşımıza çıkmaktadır. İşinden doyum alan çalışanın iş-yaşam dengesini daha kolay kurabileceğini düşünebiliriz. Çalışma saatleri açısından bakıldığında 40 saate kadar çalışma süresi olan çalışanların iş doyumunun daha fazla olduğu görülmektedir. Ortaya çıkan sonuca göre mesai süresi uzadıkça iş doyumu azalmaktadır. Salgın döneminde mesaiye çağrılmayan kişilerin iş doyumu daha yüksek çıkmıştır. Salgın dönemi herkes için belirsiz ve riskli dönem olduğu için bu dönemi fazla mesai yapmadan geçiren kişilerin iş doyumunun daha yüksek olduğu düşünülebilir.

\section{SONUÇ ve ÖNERILLER}

Gruplar arasındaki cinsiyet, vardiya şekli, mesai süresi, toplam çalışılan yıl gibi faktörlerin iş yaşam dengesi ve iş doyumunda rol oynadıkları görülmüştür. Sürekli gündüz vardiyasında ve vardiya dönüşümlü çalışan erkeklerin iş doyumları kadınlardan yüksek çıkmıştır. Sürekli gündüz vardiyasında çalışan katılımcıların iş yaşam denge puanları vardiya dönüşümlü çalışanlardan yüksek çıkmıştır. Sürekli gündüz vardiyasında görev yapan katılımcıların iş doyum puanları daha yüksek çıkmıştır. Buna göre vardiya değişimli çalışmak iş doyum düzeyini azaltmaktadır. İş doyumu ile iş-yaşam dengesi arasında pozitif yönde yüksek düzeyde ilişki olduğu ve katılımcıların çalışma yılı arttıkça iş-yaşam dengelerinin de arttığı gözlenmektedir. Mesai süresinin artışı iş doyumunu azaltmakta olup 40 saate kadar mesai yapanların iş doyum puanlarının diğer katılımcılardan daha yüksek olduğu görülmektedir.

Araştırma bulgularına göre katılımcıların yaklaşık \% 60'ının kadın olduğu görülmektedir. Erkeklerin iş doyumu daha yüksekken, iş yaşam dengesinde kadın ve erkekler için kısmen farklılık vardır. İş yaşam dengesinde cinsiyetin etkili olmadığı (Polat, ve diğerleri 2018) tarafından yapılan çalışmada da gösterilmiştir. Cinsiyet değişkeninin iş yaşam dengesinde etkisiz olduğu yine (Babacan 2020) tarafından yapılan çalışmada da ortaya çıkarılmıştır. Cinsiyetin iş doyumunu etkilemesine dair benzer çalışma 2009 yılında (Topçu 2009) tarafından yapılıp, erkeklerin iş doyumunun daha yüksek olduğunu göstermiştir. Sağlık sektöründe kadın çalışan sayısı genel olarak yüksektir.

Vardiyalı çalışanlarda anksiyete arttıkça, depresyon, yetersiz özyeterlilik algısı, stres algısı, tükenmişliğin anlamlı ölçüde arttığı, uyku kalitesinin anlamlı ölçüde bozulduğu ve mesleki tatminin ise anlamlı şekilde azaldığı bulunmuştur. Başka bir çalışma ise vardiyalı çalışan kadın güvenlik görevlilerinin iş yaşam dengesi üzerine yapılmış olup vardiya sonrasında çalışanlar; stres, uykusuzluk, yorgunluk gibi olumsuzlukları yaşadıklarını ifade etmişlerdir (Tatar 2018). Çalışmamıza benzer olarak cinsiyetin iş doyumunu etkilediğini (Kaya 2013) (Sönmez, ve diğerleri 2016) gibi çalışmalar örnek verilebilir.

Çalışma şekli ve çalışma saatlerinin kişisel yaşamlarına etkisi konusunda katılımcıların verdiği cevaplara bakıldığında 125 kişi olumsuz etkilediğini ifade ederken, 70 kişi etkilemediğini, 61 kişi olumlu etkilediğini belirtmiştir. Vardiyalı çalışmaktan memnuniyet durumu sorulduğunda 110 kişi bilmiyorum, sırasıyla 93 kişi hayır ve 43 kişi evet şeklinde cevap vermiştir (Ünal 2019). tarafından yapılan çalışmada sağlık çalışanlarına yöneltilen sorular sonucunda çalışanların çoğunun gece vardiyasından sonra uykuya dalmakta problem yaşadığg ve buna bağlı olarak vardiyalı çalışma sonucu uyku düzenleri bozulduğu; gece vardiyasının katılımcıların davranışlarını olumsuz (sinirli/agresif) etkilediği ve gece çalışmasından sonra yorgun ve stresli 
olduğu; katılımcıların vardiyalı çalışma sonucu tükenmişlik sendromu yaşadığı ve vardiyalı çalışmanın ruh sağlı̆̆ı üzerinde olumsuz bir etki yarattığı; katılımıcıların gece vardiyasından dolayı hazır gıda kullanımının arttığı ve yemek yeme (öğün) düzeninin bozulduğu; gece vardiyasının sağlık çalışanlarının fiziksel sağlıkları üzerinde olumsuz bir etki yarattığı sonucuna ulaşılmıştır. Yine uzun saatler çalışamanın olumsuz bir etkisi olarak, haftalık 40 saatin üzerinde çalışanların, yüksek alkol ve tütün ürünleri kullandıkları, erkeklerde sağlıksız kilo alımı kadınlarda ise depresyonun ortaya çıtığı görülmüştür (Popomaronis, 2020). 2017 yılında psikiyatri servisinde görevli hemşirelerin iş doyumu ve tükenmişlik düzeylerinin incelendiği araştırmada gece vardiyasında çalışan hemşirelerin iş doyum oranlarının düşük olduğu bulunmuş olup, çalışmamıza benzer sonuçlar ortaya çıkarılmıştır (Kemeröz, 2017). Yine yapılan bir diğer çalışmada vardiyalı çalışma sisteminde çalışma saatlerinin uzun olması veya gece vardiyasında çalışmaya ilişkin olumsuzluklardan dolayı kadın güvenlik görevlilerinin büyük çoğunluğu çeşitli sağlık problemleri ile karşılaşmaktadır. Bu problemlerin başında; yorgunluk, uykusuzluk gibi fizyolojik sorunlar gelmektedir (Tatar, 2018). Vardiyalı çalışanlarda depresyon, anksiyete, stres algısı ve tükenmişlik ortalama puanlarının daha yüksek, uyku kalitesinin daha bozuk, mesleki tatminin ise daha az olduğu 219 sağlık personeli üzerinde yapılan bir diğer çalışmada (Geniş, 2017) tarafından saptanmıştır. Vardiyalı çalışmanın olumlu etkisi ise yirmi kadın güvenlik görevlisi üzerinde yapılan nitel çalışmada kullanmış oldukları izin günleri olarak tespit edilmiştir. Bunun nedeni olarak, kadın güvenlik görevlilerinin çoğu izin günlerine göre günlük hayatlarını programladıklarını ifade etmişlerdir (Tatar, 2018).

Araştırma sonucuna göre vardiyalı çalışan ve çalışmayan sağlık çalışanlarının iş yaşam dengelerinin farklı olduğu ortaya çıkmıştır. Vardiyalı çalışmayan grubun iş yaşam denge puanlarının daha yüksek olduğu görülmüştür. Vardiyalı çalışmak iş yaşam dengesini olumsuz anlamda etkilemektedir. İş aile çatışmasını doğrudan etkileyen faktörlerin; haftada toplam çalışılan süre, mesai sıklı̆̆ı ve miktarı, vardiyalı çalışma sistemi gibi nedenlerin olduğu tespit edilmiştir (Greenhaus ve Beutell, 1985; Voydanoff, 1988; Netemeyer ve McMurrian, 1996). Yapılan birçok çalışma ise iş aile çatışmasına sebep olarak vardiyalı çalışmayı göstermektedir (Greenhaus ve Beutell 1985; Voydanoff, 1988; Kinnunen ve Mauno 1998; Grzywacz, 2006). Hemşireler üzerindeki çalışmada aylık ortalama mesai saati olarak çok fazla çalıştı̆̆ını düşünen hemşirelerin iş yaşam uyumu en düşük düzeyde bulunmuştur ve kendine en az zaman ayırabilen hemşireler oldukları saptanmıştır (Babacan, 2020). Normalin üzerinde çalışma iş aile çatışmasına, rol performansında yetersizliğe sebep olmakta ayrıca tükenmişlik riskinin de artmasına neden olmakatadır (Bilazer vd., 2008). Araştırmanın bir diğer sonucuna göre çalışma yılı arttıkça iş yaşam dengesininde arttığı görülmüştür. Toplamda 20 yıl ve üzeri çalışan kişilerin iş yaşam denge puanları diğer katılımcılardan yüksek çıkmışır. Bunun sebebi olarak kıdemi fazla olanların daha gerçekçi bakış açısına sahip olmaları, kişisel tecrübelerine göre gerçeğe daha yakın beklenti sahibi olmaları ve kurumun kaynaklarına ilişkin beklentilerinin daha az olması ile açılanabilir (Cordes ve Dougherty, 1997). Başka bir çalışmada ise iş aile çatışmasının en fazla 611 yıl ile 12-17 yıl arasındaki çalışan hemşirelerde yaşandığı bulunmuştur (Gürel, Özsoy ve Renginar, 2017). Hemşirelerle yapılan diğer bir çalışmada ise mesleki çalışma süresi arttıkça iş aile çatışmasının azaldığı görülmüştür (Polat vd., 2018). Araştırmamızı destekleyen bir başka bulguda Norveç'te 2095 hemşire ile yapılan çalışmadır. Çalışma sonucuna göre yaş ilerledikçe iş doyumunun yükseldiğine ulaşılmıştır (Bjork, 2007). Farklı sonuç ortaya koyan bir başka çalışmada ise hemşirelerin yaşı arttıkça iş yaşam çatışmasının arttığı ortaya çıkarılmıştır (Yıldırımalp, Öner ve Yenihan 2014).

Çalışmada bazı sınırlılıklar dikkat çekmektedir. Araştırmanın örneklemi İstanbul ili ile sınırlı kalmıştır. Farklı iller araştırmaya dâhil edilerek bulguların genellemesinde kısıtlama olmadan 
örneklem yöntemiyle tekrarlanabilir. Daha büyük gruplar ve farklı nitelikteki sağlık çalışanları dahil edilerek araştırmalar yapılabilir.

Sonuç olarak, vardiyalı ve uzun saatler çalışmanın iş yaşam dengesi ve iş doyumu üzerinde etkili olduğu belirlenmiştir. Buna bağlı olarak kurumların çalışanların iş yaşam dengelerini sağlamalarına yardımcı olacak uygulamalar sunması önem taşımaktadır. Özellikle sağlık personelinin iş yaşam dengesi ve iş doyumunun yüksek olması tüm toplum için fayda sağlayacaktır. Mesai süresi olarak 40 saatin altında çalışanların iş doyumu daha yüksek çıktığı için kurumun mesai saatlerini azaltıcı politikalar geliştirmesi gerekebilir. Çalışma saatlerinin düzenlenmesi, vardiyalı çalışan kişilere sosyal hayatlarının planlanması konusunda destek olunması, örgüt tarafından çalışma koşullarının iyileştirilmesi gibi öneriler yararlı olacak olup vardiyalı çalı̧̧manın neden olduğu durumların belirlenmesi bu çalışma gibi yeni araştırmalara ihtiyaç vardır.

\section{KAYNAKÇA}

Apaydın, Ç. (2011). Öğretim Üyelerinin İşe Bağlılık Düzeyleri ile Işs-Yaşam Dengesi ve Isş-Aile Yaşam Dengesi arasındaki İlişki. Doktora Tezi. Ankara: Ankara Üniversitesi, Eğitim Bilimleri Enstitüsü.

Babacan, B. (2020). Yoğun Bakım Hemşirelerinin İş Yaşam Dengelerinin İncelenmesi. İzmir: Ege Üniversitesi Psikiyatri Hemşireliği Anabilim Dalı.

Bilazer, F., Konca, G., Uğur, S., Uçak, H., Erdemir, F., ve Çıtak, E. (2008). Türkiye'de Hemşirelerin Çalışma Koşulları. Ankara: Türk Hemşireler Derneği Yayınları.

Bjork, I. (2007). Job Satisfaction in Norwegian Population of Nurses: A Questionnaire Survey. International Journal of Nursing Studies, 44(5), 747-757.

Cordes, C., and L. Dougherty, T. W. (1997). Patterns of Burnout Among Managers and Professionals: A Comparison of Models. Journal of Organizational Behavior, 18(6), 685-701.

Ebling, M., and Carlotto, M. S. (2012). Burnout syndrome and associated factors among health professionals of a public hospital. Trends in Psychiatry and Psychotherapy, 34(2), 93-100.

European Agency for Safety and Health at Work. (2014). Retrieved from The Business Case for Managing Stress and Psychosocial Risks: https://healthy-workplaces.eu/en/about-topic/businesscase, Erişim tarihi 01/09/2020.

Frone, M., and Mary, C. (1992). Prevalence of Work-Family Conflict: Are Work and Family Boundaries Asymmetrically Permeable? Journal of Organizational Behavior, 13(7), 728-729.

Geniş, B. (2017). Sağlık Çalı̧̧anlarında Vardiyalı Çalışma Sisteminin Uyku Kalitesi, Fiziksel Hastalıklar, Ruhsal Durum ve Yaşam Kalitesi Üzerindeki Etkileri Uzmanlık Tezi. Ankara.

Greenhaus, J., and Beutell, N. J. (1985). Sources of Conflict Between Work and Family Roles. The Academy of Management Review, 10, 76-88.

Grzywacz, J. G. (2006). Quantifying Work-Family Conflict Among Registered Nurses. Research in Nursing \& Health, 29(5), 414-426.

Guest, D. E. (2002). Perspectives on the study of work-life balance. Retrieved from Social Science Information:https://www.researchgate.net/profile/David_Guest2/publication/249732902_Perspe ctives_on_the_Study_of_Work-Life_Balance/links/58e2479caca272059ab4168a/Perspectives-onthe-Study-of-Work-Life-Balance.pdf Erişim tarihi 01/10/2020 
Gürel, S., Özsoy, S., ve Renginar, D. Ö. (2017). Aile Sağllğı Merkezlerinde Çalışan Evli Hemşirelerin İş-Aile Çatışma Düzeyini Etkileyen Faktörler. Acıbadem Üniversitesi Sağlık Bilimleri Dergisi, 3, 150-155.

https://www.cdc.gov/niosh/docs/99-101/pdfs/99-101.pdf. (2014). Stress at Work. National Institute for Occupational Safety and Health: https:/www.cdc.gov/niosh/docs/99-101/pdfs/99-101.pdf Erişim tarihi 01/10/2020

Joseph, Bobby and Joseph, Merlyn. (2016). The health of the healthcare workers. The Indian Journal of Occupational and Environmental Medicine, 20(2), 71-72.

Kaya, A. (2013). Antalya il merkezi hastanelerindeki yönetici hemşirelerin profesyonel değerler algısı ile iş doyum düzeylerinin incelenmesi. Yüksek Lisans Tezi. Antalya: Akdeniz Üniversitesi Sağllk Bilimleri Enstitüsü.

Kaya, F., ve Oğuzöncül, A. F. (2016). Birinci Basamak Sağlık Çalışanlarında İş Doyumu ve Etkileyen Faktörler. Dicle Tip Dergisi, 43(2), 248-255.

Kemeröz, K. H. (2017). Psikiyatri kliniğinde çalı̧̧an hemşirelerde iş doyumu, tükenmişlik düzeyi ve ilişkili değişkenlerin incelenmesi. Yüksek Lisans Tezi. İstanbul: Okan Üniversitesi Sağllk Bilimleri Enstitüsü.

Kinnunen, U., and Mauno, S. (1998). Antecedents and Outcomes of Work-Family Conflict Among Employed Women and Men in Finland. Human Relations, 51(2), 155-177.

Netemeyer, R., G., B. J., and McMurrian, R. (1996). Development and Validation of Work-Family Conflict and Family-Work Conflict Scales. Journal of Applied Psychology, 81(4), 400-410.

Özkul, K. (2015). Mobbingin İş Doyumuna Etkisinin Demografik Özellikler Çerçevesinde İncelenmesi, Yüksek Lisans Tezi. Ankara: Ankara Üniversitesi / Sağllk Bilimleri Enstitüsü / Disiplinlerarası Adli Bilimler Anabilim Dalı / Adli Psikoloji Bilim Dalı.

Polat, Ş., Kutlu, L., Ay, F., Erkan, A. H., ve Doğrusöz, A. L. (2018). Bir üniversite hastanesindeki hemşirelerde iş-aile çatışması ile örgütsel sessizlik ve sosyal destek algısı arasındaki ilişkiler. Psikiyatri Hemşireliği Dergisi, 5(10) 195-204.

Popomaronis, T. Science Says You Shouldn't Work More Than This Number of Hours a Week Working too much can be counterproductive and even hazardous to your health. You've been warned. Retrieved from INC Best Workplaces: https://www.inc.com/tom-popomaronis/science-says-you-shouldntwork-more-than-this-number-of-hours-a-day.html, Erişim tarihi 02/10/2020

Quick, J. C., Nelson, J. D., and Hurrel, D. L. (1997). Preventive Stress Management in Organizations. Washington DC: American Psychological Association.

Rotondo, D. M., Carlson, D. S., and Kincaid, J. F. (2003). Coping with multiple dimensions of work-family conflict. Personnel Review, 32(3), 275-296.

Sönmez, B., Sönmez, Ö., Diren, O., ve Öksüz, E. (2016). Ankara'da radyoloji teknisyenlerinin iş doyumu ve tükenme durumları: Kesitsel bir çalışma. Eurasian Journal of Family Medicine 5(1), 2532.

Tatar, T. (2018). Vardiyalı Çalışmanın Kadın Çalışanların İş-Yaşam Dengesi Üzerine Etkisi: Sakarya İli Güvenlik Sektöründe Bir Araştırma. Sakarya: Sakarya Üniversitesi Sosyal Bilimler Enstitüsü Çalışma Ekonomisi ve Endüstri İlişkileri. 
Topçu, M. Ü. (2009). Malatya İl Merkezinde Çalışan Sağhlk Personelinin İş Doyumu ve Etkileyen Faktörler. Malatya: İnönü Üniversitesi Sağlık Bilimleri Enstitüsü.

Ünal, E. (2019). Vardiyalı Çalışmanın Sosyolojik Analizi: Ceyhan Sağlık Çalışanları Örneği. Yüksek Lisans Tezi. Niğde: Niğde Öme Halisdemir Üniversitesi Sosyal Bilimler Enstitüsü Sosyoloji Anabilim Dalı.

Voydanoff, P. (1988). Work Role Characteristics, Family Structure Demands and Work/ Family Conflict. Journal of Marriage and the Family, 50(3), 749-761.

Yıldırımalp, S., Öner, M., ve Yenihan, B. (2014). Hemşirelerin İş-Aile Çatışması ve Yaşam Tatmini Düzeyleri: Demografik Özellikler Açısından Bir Değerlendirme. Siyaset, Ekonomi ve Yönetim Araştırmaları Dergisi, 2(3), 165-182.

Yılmaz, A. and Ekici, S. (2006). Örgütsel Yaşamda Kamu Çalışanlarının Örgütsel Stres Kaynakları Üzerine Bir Araştırma. Süleyman Demirel Üniversitesi İktisadi ve İdari Bilimler Fakültesi Dergisi, 10(2), 1-19.

Yüksel, İ. (2005). İş-Aile Çatışmasının Kariyer Tatmini, İş Tatmini ve İş Davranışları ile İlişkisi. Atatürk Üniversitesi, İktisadi ve İdari Bilimler Fakültesi Dergisi, 19(2), 301-314. 